\title{
Marine spatial planning and Good Environmental Status: a perspective on spatial and temporal dimensions
}

\author{
$\underline{\text { Alison J. Gilbert }}^{1}, \underline{\text { Karen Alexander }}^{2}, \underline{\text { Rafael Sardá }}^{3}, \underline{\text { Raminta Brazinskaite }}^{4}$, Christian Fischer $^{5}, \underline{\text { Kira Gee }}^{5,6}, \underline{\text { Mark Jessopp }}^{7}, \underline{\text { Peter }}$

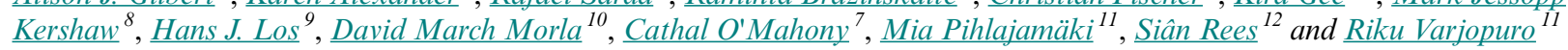

\begin{abstract}
The European Union Marine Strategy Framework Directive requires the Good Environmental Status of marine environments in Europe's regional seas; yet, maritime activities, including sources of marine degradation, are diversifying and intensifying in an increasingly globalized world. Marine spatial planning is emerging as a tool for rationalizing competing uses of the marine environment while guarding its quality. A directive guiding the development of such plans by European Union member states is currently being formulated. There is an undeniable need for marine spatial planning. However, we argue that considerable care must be taken with marine spatial planning, as the spatial and temporal scales of maritime activities and of Good Environmental Status may be mismatched. We identify four principles for careful and explicit consideration to align the requirements of the two directives and enable marine spatial planning to support the achievement of Good Environmental Status in Europe's regional seas.
\end{abstract}

Key Words: DPSWR; Good Environmental Status; marine spatial planning; maritime spatial planning; spatial scale temporal scale

\section{THE POLICY CONTEXT}

Global and regional assessments confirm that the capacity of our ocean ecosystems to continue to deliver ecosystem services that underpin human well-being is declining because of human activities (e.g., Millennium Ecosystem Assessment 2005, Dayton et al. 2005, United Nations Environment Programme 2006, Worm 2006, Worm et al. 2009). In response, the European Union (EU) is implementing the Marine Strategy Framework Directive (European Union 2008). The MSFD requires member states to apply an ecosystem approach to the management of human activities with the aim of achieving Good Environmental Status (GES) of Europe's regional seas by 2020. European marine policy is based on the Integrated Maritime Policy (European Union 2007) and aims to deliver both sustainable development and environmental protection. The IMP specifically identifies maritime spatial planning (MSP) as a tool to further its objectives by providing for arbitration among competing human activities and management of their effects on the marine environment (European Union 2008). The MSFD is the environmental pillar of the IMP and other components must work within the confines of the ecosystem approach it prescribes.

The terms maritime spatial planning and marine spatial planning, both abbreviated to MSP, may be found in the literature. The IMP and some MSP projects use the former term to emphasize a holistic cross-sectoral approach. Other authors use the latter (e. g., BaltSeaPlan, Douvere 2008, Ehler and Douvere 2009, Department of the Environment, Fisheries and Rural Affairs 2012, Jay et al. 2012), as we do to emphasize that planning is ultimately bound by the environmental limits of the marine system. Whether maritime or marine, MSP is defined as: "a process of public authorities of analyzing and allocating the spatial and temporal distribution of human activities in marine areas to achieve ecological, economic and social objectives" (Ehler and Douvere 2009:18, European Commission 2010:3). The current proposal for a directive on MSP explicitly includes environmental objectives and supports achievement of the objectives of the MSFD (European Commission 2013, Article 5 [d]). However, specifics are lacking and, given the current economic situation, there are concerns that the environment will be overlooked as Europe strives for economic recovery. Marine spatial planning comprises data collection, stakeholder consultation, participatory plan development, and subsequent stages of implementation, enforcement, evaluation, and revision (European Commission 2008, Ehler and Douvere 2009). Effective MSP responds to the need to resolve conflicts among maritime uses, and between uses and the marine environment, and provides the opportunity to address the cumulative effects of use (Douvere and Ehler 2009, European Commission 2013).

The urgency for a planning regime to coordinate maritime activities is apparent (European Commission 2008). A number of EU member states have already developed plans (e.g., Boyes et al. 2007, Calado et al. 2010, Kannen 2012, Suárez de Vivero and Mateos 2012, Kelly et al. 2014). Baltic Sea states are active in developing plans at the (sub)regional sea level (Vision and Strategies Around the Baltic Committee for Spatial Development 2010). The EU is drafting a directive on MSP specifically to give cross-border cooperation a firm legal footing (European Commission 2013). Although the responsibility for MSP lies at the national level and addresses maritime activities in a nation's Exclusive Economic Zone (EEZ), a transnational, subregional, and even a regional sea perspective is called for when maritime activities and/or their effects cross national borders (Gee et al. 2011). This creates considerable challenges for the planning process and stakeholder consultation (e.g., Argardy et al. 2011, Maritime Spatial Planning in the North Sea 2012, Halpern et al. 2012, Jentoft and Knol 2014). However, it also provides challenges for assessing effects on the marine environment given the requirement under the MSFD to achieve GES at subregional and

\footnotetext{
${ }^{1}$ Institute for Environmental Studies, VU University Amsterdam, ${ }^{2}$ Scottish Association for Marine Science, Scottish Marine Institute, ${ }^{3} \mathrm{Centre}$ d'Estudis Avançats de Blanes, Consejo Superior de Investigaciones Científicas, ${ }^{4}$ UK Department for Environment, Food and Rural Affairs, ${ }^{5}$ Institute for Coastal Research, Helmholtz-Zentrum Geesthacht, ${ }^{6}$ Department of Geography and Planning, University of Liverpool, ${ }^{7}$ Coastal and Marine Research Centre, University College Cork, ${ }^{8}$ Centre for Environment, Fisheries and Aquaculture Science, UK Department for Environment, Food and Rural Affairs, ${ }^{9}$ Deltares, ${ }^{10}$ Instituto Mediterraneo de Estudios Avanzados (IMEDEA CSIC / UIB), ${ }^{11}$ Finnish Environment Institute, ${ }^{12}$ Marine Institute, University of Plymouth
} 
regional sea scales (Articles 3[2] and 3[9]). We address effects on the marine environment by examining the spatial and temporal dimensions of both GES and MSP.

We examine the role of MSP in an ecosystem approach and MSP's potential contributions to achieving GES. We aim to assess whether mismatches of spatial and temporal scales between MSP and marine ecosystems might constrain this role and these contributions. The methodology is based on the Driver Pressure State Welfare Response (DPSWR) framework (Cooper 2013). Findings are illustrated by two case studies representing aspects of traditional and emerging sea use. We use DPSWR to provide a context for MSP in an ecosystem approach to achieve GES. We then compare the spatial and temporal scales of MSP and GES. We identify a number of principles that require explicit consideration by MSP. These principles address the specific focus of our work; namely, the spatial and temporal aspects of MSP and GES. They are intended to augment other studies of good practice (e.g., Zaucha and Matczak 2012, UNESCO 2013). We then present two case studies: (1) conservation of the reefforming, cold-water coral Lophelia pertusa, and (2) large-scale development of offshore wind farms (OWF). These case studies illustrate the range of possibilities for MSP to support the achievement of GES. Our findings are summarized in the last section where we identify ways to move forward with MSP as a tool forming part of an ecosystem approach.

\section{MARINE SPATIAL PLANNING AND GOOD ENVIRONMENTAL STATUS}

The MSFD provides a mechanism for EU member states to identify criteria and targets for GES. Those activities or uses of the marine environment that compromise environmental status must be considered explicitly when identifying management measures to achieve GES. However, the MSFD does not provide the operational framework to manage those activities (Frazão Santos et al. 2012). The implementation of MSP by individual nations provides an opportunity to develop maritime sectors sustainably and at the same time achieve GES (Suárez de Vivero and Rodríguez Mateos 2012). Humans are integral to ecosystem processes, combining to form a social-ecological system (e.g., Armsworth et al. 2007, Curtin and Prellezo 2010, Pollnac et al. 2010), and so a plan that explicitly addresses GES while rationalizing use of marine space could be an influential tool within an ecosystem approach to managing maritime activities.

The Driver Pressure State Welfare Response (DPSWR) framework is a conceptual starting point for analyzing socialecological systems (Farmer et al. 2012, Cooper 2013, Mee et al. 2015). Figure 1 locates MSP, and its interaction with GES, within this framework. This figure distinguishes a spatially-bounded, planned area within the larger marine environment. In the planned area, MSP determines the mix of drivers and their expected pressures. Good Environmental Status descriptors are used to elaborate expected state changes. Eleven quality descriptors of GES are identified by the MSFD. They may be classified as pressure or state descriptors (Cochrane et al. 2010; see Table 1). Pressure descriptors identify acceptable levels of pressures and so are implicitly linked to sustainable use; state descriptors specify the desired state of the ecosystem. Both types of descriptors determine whether GES is achieved. A response is triggered should GES not be achieved. A response could be either plan revision following an environmental impact assessment, or plan adaptation if the plan is already in place. Figure 1 suggests that a response is triggered irrespective of the welfare implications of not achieving GES. Clearly effects on societal welfare will determine the urgency for a response, as illustrated by the emergency closure of the Darwin Mounds following public outcry about trawling damage (European Council 2003).

Fig. 1. Marine spatial planning (MSP) and Good Environmental Status (GES) within the Driver Pressure State Welfare Response (DPSWR) framework.

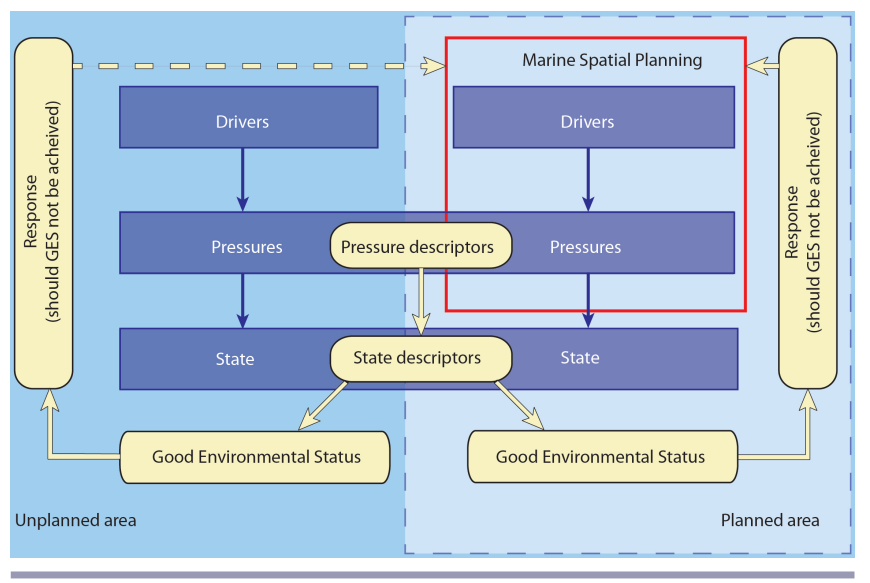

As the marine environment is not a closed system, pressures may derive from drivers outside a planned area and activities within a planned area may cause pressures beyond the planned area. In the former instance, external sources of pressures will need to be considered in making plans. For example, nutrient loads from land-based sources might place limits on aquaculture development because the combined loads cause eutrophication (descriptor 5, or D5, in Table 1). In the latter instance, plans will need to take "downstream" effects into account, but will a response be triggered should GES be compromised elsewhere? This line is dashed in Fig. 1. Governance arrangements may not be in place for such a response, particularly for transboundary effects. The proposed directive on MSP (European Commission 2013) specifically addresses this issue (Article 6[2]); assessment of the environmental effects of a plan will be subject to the provisions of the Directive on Strategic Environmental Assessment (Directive 2001/42/EC, Article 11; European Union 2001).

In rationalizing maritime activities for a given area and determining the pressures being placed on the marine environment, MSP has the potential to become an important tool within an ecosystem approach to achieve GES. However, its focus so far has been primarily with the area being planned. There is growing recognition that MSP's environmental objective will only be met when MSP also addresses environmental effects beyond the planned area (e.g., BaltSeaPlan, see Kappeler et al. 2012). Consequently, we derive the first of four environmental principles for MSP:

A given plan will need review and modification if achieving or maintaining GES in the planned area is threatened. To support effective implementation, robust governance and institutional arrangements, supported by an EU directive, are needed. 
Table 1. The qualitative descriptors for Good Environmental Status (GES) $\dagger$.

\begin{tabular}{|c|c|c|c|}
\hline \# & Goal of qualitative descriptor & $\begin{array}{c}\text { Abbreviated name of } \\
\text { descriptor }\end{array}$ & $\begin{array}{c}\begin{array}{c}\text { Pressure or state } \\
\text { descriptor: }\end{array} \\
\end{array}$ \\
\hline (D1) & $\begin{array}{l}\text { Biological diversity is maintained. The quality and occurrence of habitats and the } \\
\text { distribution and abundance of species are in line with prevailing physiographic, } \\
\text { geographic and climatic conditions. }\end{array}$ & biological diversity & state \\
\hline (D2) & $\begin{array}{l}\text { Non-indigenous species introduced by human activities are at levels that do not } \\
\text { adversely alter the ecosystems. }\end{array}$ & non-indigenous species & pressure \\
\hline (D3) & $\begin{array}{l}\text { Populations of all commercially exploited fish and shellfish are within safe biological } \\
\text { limits, exhibiting a population age and size distribution that is indicative of a healthy } \\
\text { stock. }\end{array}$ & commercial fish & pressure \\
\hline (D4) & $\begin{array}{l}\text { All elements of the marine food webs, to the extent that they are known, occur at } \\
\text { normal abundance and diversity and levels capable of ensuring the long-term abundance } \\
\text { of the species and the retention of their full reproductive capacity. }\end{array}$ & food webs & state \\
\hline (D5) & $\begin{array}{l}\text { Human-induced eutrophication is minimized, especially adverse effects thereof, such as } \\
\text { losses in biodiversity, ecosystem degradation, harmful algae blooms, and oxygen } \\
\text { deficiency in bottom waters. }\end{array}$ & eutrophication & pressure \\
\hline (D6) & $\begin{array}{l}\text { Sea-floor integrity is at a level that ensures that the structure } \\
\text { and functions of the ecosystems are safeguarded and benthic ecosystems, in particular, } \\
\text { are not adversely affected. }\end{array}$ & sea-floor integrity & state \\
\hline (D7) & $\begin{array}{l}\text { Permanent alteration of hydrographical conditions does not adversely affect marine } \\
\text { ecosystems. }\end{array}$ & $\begin{array}{l}\text { hydrographical } \\
\text { conditions }\end{array}$ & pressure \\
\hline (D8) & Concentrations of contaminants are at levels not giving rise to pollution effects. & contaminants & pressure \\
\hline (D9) & $\begin{array}{l}\text { Contaminants in fish and other seafood for human consumption do not exceed levels } \\
\text { established by Community legislation or other relevant standards. }\end{array}$ & $\begin{array}{l}\text { contaminants in } \\
\text { seafood }\end{array}$ & pressure \\
\hline (D- & $\begin{array}{l}\text { Properties and quantities of marine litter do not cause harm tothe coastal and marine } \\
\text { environment. }\end{array}$ & marine litter & pressure \\
\hline (D- & $\begin{array}{l}\text { Introduction of energy, including underwater noise, is at levels that do not adversely } \\
\text { affect the marine environment. }\end{array}$ & $\begin{array}{l}\text { energy and underwater } \\
\text { noise }\end{array}$ & pressure \\
\hline
\end{tabular}

This principle addresses the governance context of MSP and GES. The remaining principles specifically address spatial and temporal scales.

\section{MARINE SPATIAL PLANNING AND SPATIAL AND TEMPORAL SCALES}

Marine spatial planning has been initiated in a number of countries (UNESCO 2013), frequently drawing on land-use planning (Boyes et al. 2007, Calado et al. 2010). However, this overlooks fundamental differences between terrestrial and marine environments in terms of their spatial and temporal scales. The sea has a clear, three-dimensional spatial scale that is difficult to represent on two-dimensional maps. Use of the sea occurs: (1) on the water surface, e.g., shipping; (2) in the water column, e.g., aquaculture; (3) on the sea-floor, e.g., benthic trawling; (4) in the seafloor, e.g., cables; and (5) all at once, e.g., oil and gas extraction, and deep-sea mining. Relative to the marine environment, the terrestrial environment is more temporally static. The physical forces associated with water in constant motion are much greater than those of air and can cause rapid, periodic, and episodic changes in physical conditions. Further, many maritime activities are mobile, e.g., fishing and shipping. The pressures they place on the environment may not be constant over time and/or may not emanate from distinct spatial locations.

This section draws on the Driver Pressure State Welfare Response (DPSWR) framework and uses its terminology to address the spatial and temporal scales associated with GES descriptors and to identify their possible implications for MSP. We begin with spatial scales. A maritime activity, or driver, may place pressure on environments beyond its allotted area of operation and even beyond the planned area. Conflicts among users can arise when a state change caused by one maritime activity compromises another. An example is sand extraction that leads to sedimentation in nearby fish-spawning grounds. Rationalizing such conflicts is part of the purpose of MSP. Marine spatial 
Table 2. Spatial planning characteristics of Marine Strategy Framework Directive (MSFD) descriptors.

\begin{tabular}{|c|c|c|}
\hline Qualitative descriptor & Drivers subject to MSP & Drivers not subject to MSP \\
\hline (D1) Biological diversity $\dagger$ & $\begin{array}{l}\text { environmental protection } \neq \text {, renewable energy generation (wind, wave, and tidal } \\
\text { energy), cables and pipelines, oil and gas exploitation, sand and gravel } \\
\text { extraction, benthic trawling, anchoring, other infrastructure }\end{array}$ & \\
\hline $\begin{array}{l}\text { (D2) Nonindigenous } \\
\text { species }\end{array}$ & $\begin{array}{l}\text { aquaculture, recreational boating, shipping, offshore wind farms, oil and gas } \\
\text { exploitation, other infrastructure, and sources of new or altered habitat }\end{array}$ & $\begin{array}{l}\text { aquaria (release of non-indigenous } \\
\text { species) }\end{array}$ \\
\hline $\begin{array}{l}\text { (D3) Commercial fish and } \\
\text { shellfish } \dagger\end{array}$ & $\begin{array}{l}\text { environmental protectiont, fisheries (especially gear types and discarding), } \\
\text { offshore wind farms, oil and gas, aquaculture }\end{array}$ & $\begin{array}{l}\text { other, more mobile fisheries and } \\
\text { including illegal fishing }\end{array}$ \\
\hline (D4) Marine food webs & viewed as being covered by the other descriptors & \\
\hline (D5) Eutrophication & aquaculture, shipping (NOx production, wastewater release) & $\begin{array}{l}\text { land-based sources of nutrients, } \\
\text { such as agriculture and urban } \\
\text { wastewater }\end{array}$ \\
\hline (D6) Seafloor integrity $\dagger$ & $\begin{array}{l}\text { benthic trawling, maintenance of shipping lanes, land reclamation, cables and } \\
\text { pipelines, oil and gas exploitation, renewable energy generation, sand and gravel } \\
\text { extraction, anchoring, other infrastructure }\end{array}$ & \\
\hline $\begin{array}{l}\text { (D7) Hydrographical } \\
\text { conditions } \dagger\end{array}$ & $\begin{array}{l}\text { maintenance of shipping lanes, land reclamation, renewable energy generation, } \\
\text { other infrastructure }\end{array}$ & \\
\hline (D8) Contaminants & $\begin{array}{l}\text { legacy sites from past disposal of wastes and dredge spoil, shipping lanes and oil } \\
\text { platforms }\end{array}$ & $\begin{array}{l}\text { land-based sources of } \\
\text { contaminants, such as industry, } \\
\text { agriculture, and urban wastewater }\end{array}$ \\
\hline $\begin{array}{l}\text { (D9) Contaminants in } \\
\text { seafood }\end{array}$ & fisheries and aquaculture & $\begin{array}{l}\text { land-based sources of } \\
\text { contaminants }\end{array}$ \\
\hline (D10) Marine litter & & $\begin{array}{l}\text { large variety of drivers, both past } \\
\text { and present, and including land- } \\
\text { based sources }\end{array}$ \\
\hline $\begin{array}{l}\text { (D11) Energy and } \\
\text { underwater noise } \dagger\end{array}$ & shipping and offshore wind farms, but potentially a large variety of sources & \\
\hline
\end{tabular}

planning is a national responsibility although the principle of subsidiarity may devolve responsibility to lower spatial scales. Areas with multiple use of, and multiple pressures on, the marine environment may require detailed spatial plans with a fine resolution in comparison with plans at an EEZ or subregional sea level. Clearly, plans within a nation's EEZ need to be spatially coherent, but they will also need to be coherent with neighboring EEZs up to the level of the marine subregion or region. This leads to our second principle, which reinforces lessons learned from transnational projects such as BaltSeaPlan:

As GES is to be achieved at subregional or regional sea levels (Marine Strategy Framework Directive, Article 3[5], Article 4; European Union 2008), MSP needs to be coherent at multiple spatial scales.

Of the eleven GES descriptors, three are place-specific; they have a spatial character that can directly be affected by MSP. Hydrographical conditions, D7, and energy and underwater noise, D11, encompass anthropogenic sources of pressure that can be regulated by spatial planning; seafloor integrity, D6, will reflect the cumulative effects on the planned benthic environment of all pressures. Two additional descriptors are partially placespecific because of their dependence on benthic habitats: biodiversity, D1, with regards to benthic species and habitats, and commercial fish and shellfish, D3, with regards to spawning and nursery grounds. Table 2 considers GES descriptors and identifies drivers that influence them. Note that interactions among descriptors occur but are not addressed. The list of drivers is indicative rather than exhaustive. Our purpose is to distinguish between drivers potentially subject to spatial planning and the descriptors they are likely to influence, and drivers beyond the remit of MSP but with pressures that might need explicit consideration when developing plans.

Almost all descriptors, and particularly the three place-specific descriptors, are influenced by drivers whose activities could be regulated by MSP. Five descriptors, that is, (1) eutrophication, D5, (2) contaminants, D8, (3) contaminants in seafood, D9, (4) marine litter, D10, and (5) energy and underwater noise, D11, could be adversely affected by drivers not subject to MSP. 
Table 3. Capacity for change in driver activity following marine spatial planning (MSP) review.

\begin{tabular}{|c|c|c|c|}
\hline Driver & $\begin{array}{l}\text { Can be } \\
\text { curtailed }\end{array}$ & $\begin{array}{l}\text { Can be } \\
\text { stopped }\end{array}$ & Comment \\
\hline Environmental protection & yes & yes & \\
\hline \multicolumn{4}{|l|}{ Energy exploitation } \\
\hline -oil and gast & some aspects & no & $\begin{array}{l}\text { causes semipermanent environmental change; longevity of activity likely } \\
\text { to exceed time horizon of plan }\end{array}$ \\
\hline -renewable energy generation $\dagger$ & some aspects & no & $\begin{array}{l}\text { causes semipermanent environmental change; longevity of activity likely } \\
\text { to exceed time horizon of plan }\end{array}$ \\
\hline Sand and gravel extraction $\dagger$ & yes & no & $\begin{array}{l}\text { although resources may exist elsewhere, licensing agreements with a time } \\
\text { horizon longer than a marine spatial plan or its periodic review may } \\
\text { prevent major change }\end{array}$ \\
\hline Fisheries & & & economic viability of this driver likely to be adversely affected \\
\hline -benthic trawling & yes & & \\
\hline -gear type & yes & & \\
\hline -aquaculture & yes & & \\
\hline \multicolumn{4}{|l|}{ Shipping } \\
\hline -maintenance of shipping lanes $\dagger$ & yes & no & $\begin{array}{l}\text { depends on the scale of MSP as many shipping lanes are subject to } \\
\text { international agreement }\end{array}$ \\
\hline -NOx production and deposition $\dagger$ & yes & no & $\begin{array}{l}\text { depends on the scale of MSP; many shipping lanes are subject to } \\
\text { international agreement }\end{array}$ \\
\hline -anchoring & yes & yes & \\
\hline Recreational boating and marinas & yes & yes & infrastructure associated with marinas might presents constraints \\
\hline Cables and pipelines $\dagger$ & some aspects & no & $\begin{array}{l}\text { adverse effects caused while placing them in the seafloor would be } \\
\text { exacerbated with their removal and/or relocation }\end{array}$ \\
\hline Other infrastructure $\dagger$ & no & no & $\begin{array}{l}\text { depends on whether new or altered habitats are created and on their } \\
\text { permanency }\end{array}$ \\
\hline Land reclamation $\dagger$ & no & no & permanent hydrographical change \\
\hline $\begin{array}{l}\text { Legacy sites associated with past disposal } \\
\text { of wastes and dredge spoil } \dagger\end{array}$ & no & no & past environmental and hydrographical change \\
\hline
\end{tabular}

Effective MSP would need to avoid aggravating problems. Marine litter, D10, lacks MSP-relevant attributes, although clearly litter production by planned activities requires regulation. However, we conclude from Table 2 that MSP, in its regulation of the drivers and pressures, could make a significant contribution to achieving GES.

From the perspective of temporal scales, MSP yields plans with a time horizon and periodic review. A horizon of $20 \mathrm{yrs}$ or longer, with review every five to seven yrs, is common (Gilliland and Laffoley 2008). Periodic review suggests adaptive management, which is a structured, iterative process of robust decision making in the face of uncertainty (e.g., Holling 1978). It is then theoretically possible to adapt a plan should unforeseen environmental effects emerge or should environmental effects be less severe than envisaged. However, plan adaptation, and specifically curtailing or stopping activities that cause unexpectedly adverse environmental effects, may not be possible. Aside from economic considerations, stakeholder resistance, and licensing agreements, legacy effects, and the effects of committed behaviors (see O'Higgins et al. 2014) may mean that plans are not adaptable.

To illustrate further, Table 3 details drivers identified in Table 2 and assesses whether their activities might be modified or stopped should they compromise GES. Modification encompasses the reduction, relocation, and timing of activities. For example, gravel extraction or offshore wind farm (OWF) construction could be proscribed when fish are spawning (International Council for the Exploration of the Sea 2012). Cessation might be called for should the environmental effects prove unacceptably severe. For example, benthic trawling might compromise seafloor integrity, D6, or the hard substrate provided by wind turbines might facilitate species invasions, D2. Table 3 shows that a number of drivers, while regulated by MSP, may not be responsive to plan review.

The drivers indicated in Table 3 are also listed in Table 2 as those affecting the three place-specific descriptors. This leads to a third principle: 
Table 4. Matrix illustrating how the marine spatial planning (MSP) aspects of the Lophelia and offshore wind farm (OWF) case studies relate to the Marine Strategy Framework Directive (MSFD) descriptors.

\begin{tabular}{|c|c|c|c|c|c|c|c|c|c|c|c|}
\hline \multirow[t]{2}{*}{ Case study } & \multicolumn{11}{|c|}{ Descriptors $\dagger$} \\
\hline & $\begin{array}{l}\text { biological } \\
\text { diversity }\end{array}$ & $\begin{array}{c}\text { non- } \\
\text { indigenous } \\
\text { species }\end{array}$ & $\begin{array}{l}\text { commercial } \\
\text { fish }\end{array}$ & food webs & $\begin{array}{l}\text { eutrophic- } \\
\text { ation }\end{array}$ & $\begin{array}{l}\text { sea-floor } \\
\text { integrity }\end{array}$ & $\begin{array}{l}\text { hydrogra- } \\
\text { phic } \\
\text { changes }\end{array}$ & $\begin{array}{l}\text { contamin- } \\
\text { ants }\end{array}$ & $\begin{array}{l}\text { contamin- } \\
\text { ants in } \\
\text { seafood }\end{array}$ & $\begin{array}{c}\text { marine } \\
\text { litter }\end{array}$ & $\begin{array}{c}\text { energy } \\
\text { and noise }\end{array}$ \\
\hline Lophelia & + & 0 & + & + & 0 & + & 0 & 0 & 0 & + & 0 \\
\hline OWF & \pm & - & + & \pm & 0 & - & \pm & 0 & 0 & 0 & - \\
\hline \multicolumn{12}{|c|}{$\begin{array}{l}\dagger \text { See Table } 1 \\
+ \text { indicates that MSP may contribute to achieving GES } \\
\text { - indicates MSP will negatively impact GES descriptors } \\
\pm \text { indicates there may be both positive and negative effects } \\
0 \text { indicates no perceived relationship }\end{array}$} \\
\hline
\end{tabular}

Maritime activities that are less amenable to review, and with the potential to adversely affect place-specific descriptors, i.e., hydrographical changes, D7, energy and underwater noise, D11, and seafloor integrity, D6, require explicit and careful examination during the preparation of the Environmental Impact Assessment as required under the Directive on Strategic Environmental Assessment (Directive 2001/42/EC; European Union 2001).

The higher mobility of maritime activities could mean that cumulative effects are more likely in the marine, than in the terrestrial, environments. Cumulative effects may compromise achievement of GES (see Busch et al. 2013). Trends in state descriptors, D1, D4, and D6 (Cochrane et al. 2010 and Table 1) representing aggregate properties of ecosystems will reflect cumulative effects, but not necessarily in a way that disentangles and apportions their causes. Further, a key question for MSP is to what extent a negative effect can be offset by a positive one; e. g., the negative effects of OWF on seabed integrity, D6, versus the positive effect of their hard substrates on biodiversity, D1. In assessing and/or reconciling cumulative effects, MSP has the potential for contributing more to an ecosystem approach than just supporting achievement of GES. This leads to our fourth principle:

Marine spatial planning's environmental objective means that it needs to address cumulative effects and make trade-offs between pressures and environmental effects. Frameworks to assess effects, together with a stakeholder process, are needed for effective resolution of conflicts between maritime uses and the marine environment.

Whereas MSP offers much as a tool within an ecosystem approach, there is considerable potential for spatial and temporal mismatching between MSP and GES, with benthic environments most at risk. Various tools and processes exist to ensure that the temporal and spatial scales of drivers, pressures, and states are addressed by individual plans and that any mismatches are resolved. Strategic Environmental Assessment following the SEA Directive (Directive 2001/42/EC; European Union 2001) might provide a sound vehicle for assessing the interaction between MSP and MSFD and ensuring that the temporal and spatial scales of drivers, pressures, and states are addressed by individual plans.
This directive might also provide the means for assessing spatial coherence among plans so that subregional and regional sea perspectives are accommodated. A subsequent challenge is then to explore how a given plan and its environmental assessment can be translated into management measures that are adaptable over time and capable of responding to undesirable environmental change.

\section{TWO CASES ELABORATING INTERACTIONS BETWEEN MSP AND GES}

We offer two cases to illustrate the potential and the risks associated with MSP. The first relates to a traditional sea use, fisheries, and deals with known conflicts between conservation and fishing interests in the northeast Atlantic. This case illustrates the potential of MSP to resolve conflicts because MSP does not need to address the above principles in any significant way. The second relates to an emerging sea use and uncertain environmental effects with the development of OWF in the North Sea. Here, MSP must deal with all four principles if it is to support achievement of GES. Interactions, both positive and negative, between spatial planning aspects of the cases and the MSFD descriptors are scored in Table 4, assessing whether or not MSP could support the achievement of GES. Scores are discussed further below. Table 5 shows the relevance of each principle for each case study.

\section{Conservation of Lophelia reefs}

Lophelia pertusa is a reef-building deepwater coral, is particularly slow-growing, and typically inhabits depths of 200-1000 m throughout the north Atlantic. Fisheries is a key driver affecting this marine environment. Although the destructive effect of fishing on these biogenic reefs is well established (Hall-Spencer et al. 2002, Davies et al. 2007), there is also a cost to the fishing industry (welfare) through damage to or loss of nets. This case study examines the sustainability of deepwater fisheries and coldwater biogenic reefs, and the effectiveness of establishing Marine Protected Areas (MPAs), to conserve Lophelia pertusa (HallSpencer et al. 2009). The designation of such areas clearly has an MSP element.

Several GES descriptors interact with the MPA planning aspect of this study. For D1, biological diversity, planning for a "notake" MPA could prevent further destruction of reefs by trawlers and preserve habitat/nursery areas for associated species (Roberts and Polunin 1993). D3, requiring healthy stocks of commercially 
Table 5. Relevance of four principles to the two case studies.

\begin{tabular}{|c|c|c|}
\hline Principle & Lophelia case study & Offshore wind farm case study \\
\hline $\begin{array}{l}\text { A given plan will need review and modification } \\
\text { if achieving or maintaining Good } \\
\text { Environmental Status in the planned area is } \\
\text { threatened. Governance arrangements } \\
\text { (supported by an EU directive) are needed to } \\
\text { clarify responsibilities should planned }\end{array}$ & $\begin{array}{l}\text { Marine Protected Areas are expected to have } \\
\text { benefits beyond the planned area. As sites are } \\
\text { discrete and largely within national exclusive } \\
\text { economic zones (EEZs), current governance } \\
\text { arrangements are probably adequate to enable } \\
\text { plan review. }\end{array}$ & $\begin{array}{l}\text { Most North Sea riparian nations are } \\
\text { independently developing offshore wind farms, } \\
\text { each with potential environmental effects outside } \\
\text { the bounds of national marine spatial plans } \\
\text { (MSP). Governance arrangements are needed. } \\
\text { This principle is very relevant. }\end{array}$ \\
\hline
\end{tabular}

activities compromise Good Environmental

Status (GES) outside the planned area.

Since GES is to be achieved at subregional or regional sea levels (MSFD Article 3(5), Article 4), MSP needs to be coherent at multiple spatial scales.

Maritime activities that are less amenable to review and with the potential to adversely affect place-specific descriptors require explicit and careful examination during the preparation of an Environmental Impact Assessment.

MSP's environmental objective means that it needs to address cumulative effects and to make tradeoffs between pressures and environmental effects; frameworks to assess effects, together with a stakeholder process, needed for effective resolution of conflicts between maritime uses and the marine environment.
Coherence of plans across known occurrences of deep water corals could become an issue.

Both an MPA and fishing activities are amenable to review.
The potential for adverse environmental impact at large spatial makes this principle very relevant.

The longevity of offshore wind farms and the issue of decommissioning reduce the capacity to revise plans making this principle very relevant.
The combined effects of ocean acidification and fisheries pressure need to be addressed. There are only two stakeholders involved and a plan is potentially capable of creating a win-win situation.
Diversity of possible cumulative effects as well as effects that positively as well as negatively affect the environment. Framework for assessing these affects and a stakeholder process are urgently needed. exploited species, could also be positively affected through MSP. The spatial exclusion of fishing effort from reefs should lead to increased spawning stock biomass within the MPA (Sale et al. 2005). Fish move on and off the reef, and so into and out of the MPA. Restored stocks in the MPA can directly benefit fisheries so that the effect of the MPA extends beyond its immediate boundaries. D4, requiring healthy food webs, could also be positively affected. A cessation of trawling activities should also lead to the recovery of benthic communities within the MPA (Hiddink et al. 2006), thus contributing to D6, seafloor integrity. An additional benefit of a "no-take" MPA is reduced potential for nets to be snagged on or wrapped around coral reefs, thereby contributing to a decrease in marine litter, D10, as well as reducing costs to the fishing industry.

This case study demonstrates the potential of MSP to benefit both maritime activities and the marine environment. This positive outcome is affected by three factors that create a win-win situation. Firstly, Lophelia pertusa is a stationary species supporting reef communities found at discrete locations, although the species being fished are mobile. The benefits of MPA protection given to discrete sites extend beyond the sites. Secondly, fishermen wish to avoid reefs to protect their gear and so may tolerate exclusion zones. Thirdly, the environmental effects of both maritime activities are on-site and spatially contained, and so can be planned. This stands in sharp contrast to the second case study.

\section{Offshore wind farms}

The need for energy security (Bielecki 2002) and a low-carbon economy (Hoffert et al. 2002) has led to rising support for renewable energy. Wind energy is one of the most advanced renewable energy technologies. Offshore wind farms are likely to be a growth area in Europe, with widespread availability of suitable locations, abundance of wind resources throughout much of Europe's marine domain, and the perception that offshore renewable energy generation reduces issues around onshore sites (Haggett 2008, Ladenburg 2008). Offshore wind-farm development is becoming a major maritime activity requiring space, as indicated by plans to develop wind farms by most North Sea riparian states (Kannen 2012). Offshore wind farm development is expected to be a key pressure on the marine environment in the future. The MSP element of this case study relates to the location of large-scale OWFs in the North Sea, including state changes and cumulative effects, user conflicts, and governance.

The location of OWFs has a clear spatial element, being constrained by factors such as wind resource, sediment type, distance from land, and bathymetry. Given other users of marine space such as fisheries and shipping, the location of OWFs becomes an issue for MSP. Developers require guaranteed use of areas for a number of yrs, and even decades, to ensure financial return on investment. Planning for OWFs is likely to affect several GES descriptors (Table 4). 
Biological diversity, D1, may be affected both positively and negatively at different sites and during the several phases of the OWF life cycle. There is the potential for habitat loss and disturbance leading to a reduction in biodiversity during construction (Petersen and Malm 2006); changes in sedimentation, particularly from piling activities during construction, may also lead to effects such as the smothering of some species (Airoldi 2003); there may be an increase in biodiversity with pylons acting as artificial reefs or encouraging fish aggregation during operation (Punt et al. 2009), but the area may also be avoided by some seabird species (Busch et al. 2013); the behavioral responses of higher predators such as marine mammals during the operational phase is largely unknown but likely to be quite complex. The effects of decommissioning are currently unknown. Offshore wind farms are likely to compromise D2, as their hard substrate, provided by pylons, could act as 'stepping stones' and to facilitate the spread of nonindigenous species (Brodin and Andersson 2009). This is a good example of environmental effects that may occur at multiple spatial - within and beyond the planned area - and temporal - at least over the lifetime of the OWF-scales. For D3, OWFs could have a positive effect on commercial fish stocks given the exclusion of fisheries or changes in the type of gear permissible for use in the vicinity of OWFs (Fayram and de Risi 2007). This effect would be felt beyond the planned area, and so could lead to increased fishing effort at the peripheries of OWF sites (Wilhelmsson et al. 2006). There may be a negative impact upon D6, seafloor integrity, due to pile driving during construction, but a positive impact due to exclusion of destructive trawling activities during both construction and operational phases. Changes to D7, hydrographic conditions, may cause changes in sedimentation and erosion patterns (Falcão et al. 2009).

The key descriptor likely to be affected most by OWF development is D11, through the introduction of energy, including underwater noise. Noise during construction, particularly the cumulative noise from seismic surveying or piledriving activities, is likely to exceed levels that can cause hearing threshold shifts, behavioral responses such as displacement in marine mammals (Southall et al. 2007 and see paragraph above), or could affect fish spawning aggregations. Behavioral response of marine mammals has been noted at distances exceeding $10 \mathrm{~km}$ from wind farm construction (Tougaard et al. 2005). Noise generated during the operational phase may mask or interfere with biological signals used by marine mammals (Carstensen et al. 2006) and fish species (Wahlberg and Westerberg 2005). Given the mobility of these species and the long distances sound can travel underwater, effects may extend well beyond that of the OWF and the planned area.

This case study demonstrates that our understanding of how maritime activities affect marine ecosystem functioning is not yet sufficient for MSP to resolve conflicts. It also highlights potential interactions between the MSFD and other EU policies such as the EU Renewable Energy Sources Directive, the Common Fisheries Policy, Blue Growth, and the proposed MSP directive. In contrast to the first case study, OWF is in direct competition with other maritime activities for space and, while many environmental effects are on-site, there are a number of potential effects at much larger spatial, including transboundary, and temporal scales.

\section{Conclusions from the case studies}

Both case studies highlight the need to address temporal scales. Some positive and negative interactions with the marine environment may not emerge until the medium to long term, and even not during the time horizon of a plan. Positive effects of an MPA to conserve Lophelia communities, on fish stocks but also on biological diversity and seafloor integrity, are likely in the medium to long term, but may be confounded by longer term environmental change, such as ocean acidification (see O'Higgins et al. 2014). This needs to be considered when making and reviewing the plan. A review period of five to six yrs and a plan horizon of $20 \mathrm{yrs}$ may be too short to measure and evaluate the impacts of planning provisions. Offshore wind farms are likely to be operational for around $30 \mathrm{yrs}$ and a plan horizon that includes their construction, operation, and decommissioning would seem desirable. Once the infrastructure is in place, little can be done at that site to redress adverse effects on, for example, seafloor integrity or nonindigenous species. Review may need to focus on other environmental pressures that are subject to shortterm variation, such as energy and noise or the presence of seabird populations, although monitoring should be installed to track long-term trends. Review would also be needed to assess whether other activities sited in the vicinity of an OWF would mitigate or compound environmental effects. Finally, MSP cannot be conducted in isolation from other activities. Designation of an MPA, or location of an OWF, requires assessment of the effects on displaced marine activities. In both case studies, fisheries are likely to be affected. Changes in pressures from these displaced activities will have an effect on GES descriptors both in the planned area and beyond. Planners and regulators will also need to address cumulative effects and their expression at different temporal and spatial scales.

\section{MOVING FORWARD WITH MARINE SPATIAL PLANNING IN AN ECOSYSTEM APPROACH}

We have examined MSP as a tool within an ecosystem approach to achieve Good Environmental Status for Europe's regional seas with a specific focus on associated spatial and temporal dimensions. Marine spatial planning rationalizes and allocates space to maritime uses, and so modulates subsequent pressures on marine states. We have proposed four principles for embedding MSP in an ecosystem approach:

1. A given plan will need review and modification if achieving or maintaining GES in the planned area is threatened. Governance arrangements, supported by an EU directive, are needed to clarify responsibilities should planned activities compromise GES outside the planned area.

2. Since GES is to be achieved at subregional or regional sea levels (Marine Strategy Framework Directive Article 3[5], Article 4; European Union 2008), MSP needs to be coherent at multiple spatial scales.

3. Maritime activities that are less amenable to review, and with the potential to adversely affect place-specific descriptors, i.e., hydrographical changes, D7, energy and underwater noise, D11, and seafloor integrity, D6, require explicit and careful examination during the preparation of the Environmental Impact Assessment as required under the Directive on Strategic Environmental Assessment (Directive 2001/42/EC; European Union 2001). 
4. Marine spatial planning's environmental objective means that it needs to address cumulative effects and make tradeoffs between pressures and environmental effects. Frameworks to assess effects, together with a stakeholder process, are needed for effective resolution of conflicts between maritime uses and the marine environment.

We conclude that MSP, by resolving conflicts and regulating maritime activities that are drivers of state changes, can make a significant contribution to achieving GES. As a general point, we highlight that coherent planning at the (sub)regional sea scale will require a durable culture of continuing cross-border sharing of MSP-relevant information. Despite the anticipated directive on MSP, this cannot be prescribed by law. Cross-border cooperation will need further attention, particularly for seas shared with nonEU nations. Regional seas conventions could play a pivotal role here (see also Cinnirella et al. 2014). As a specific point, we recommend that in-depth enquiries with selected stakeholders take place to assess how common and how severe the spatial and temporal mismatches between MSP and GES might be.

Our conclusions about the potential of MSP for achieving GES are reinforced by the Lophelia pertusa case study. However, the principles above emphasize that there is also considerable potential for a spatial and temporal mismatch between MSP and GES. Good environmental status descriptors that specifically target place-specific, benthic environments, D6 and D7, are most under threat from maritime activities to be regulated by MSP. The case study dealing with OWFs highlights the difficulty in using MSP to regulate environmental pressures that span multiple spatial and temporal scales, e.g., nonindigenous species and migratory bird species, key drivers that may not be susceptible to a reduction of their activities during review cycles, and drivers that might contribute to cumulative effects. The two case studies illustrate possible extremes in the usefulness of MSP for achieving GES.

Although we assess MSP as a tool within an ecosystem approach, we emphasize that MSP is a process and not a tool for managing the sea. Marine spatial planning can regulate some drivers (Tables 2 and 3 ) and their associated pressures. Given the complexity of integrating ecological, social, and economic demands within a specific spatial and temporal context, classical risk analysis can support a managerial structure that facilitates and informs planning and the implementation of planned activities, and aids in the decision-making processes of action. Marine spatial planning can play an important role because it is at the revision and planning phases of policy formation where strategies are developed for management. Marine spatial planning does not necessarily lead to plans that are "set in stone." Although allocating space for maritime uses implies licensing spatial zones for many yrs, and sometimes decades, negative effects on GES can prompt adjustment of licenses during subsequent management cycles. Careful decisions need to be made regarding plans' time horizons and periodic review cycles to match the temporal scales of drivers, pressures, and subsequent state changes. Decisions can, to some extent, be adjusted while gaining experience in the use of these tools.

Finally, MSP and GES represent different perspectives on the marine environment. Marine spatial planning focuses on human use while GES focuses on environmental quality. However, MSP also has an environmental objective and GES promotes sustainable use of marine goods and services. Both are relevant for sustainable development. Some elements of GES have a placespecific component that will respond directly to spatial planning. Marine spatial planning can be used to support achievement of descriptor goals provided that the four principles identified above are taken explicitly into consideration. In this way, MSP can be embedded in an ecosystem approach.

Responses to this article can be read online at: http://www.ecologyandsociety.org/issues/responses. $\mathrm{php} / 6979$

\section{Acknowledgments:}

This work was part of the EU-funded FP7 Knowledge-based Sustainable Management for Europe's Seas (KnowSeas-226675) project. The KnowSeas project is affiliated with LOICZ and LWEC. We wish to thank our KnowSeas colleagues for their contributions to, and feedback on, our ideas for this paper.

\section{LITERATURE CITED}

Airoldi, L. 2003. The effects of sedimentation on rock coast assemblages. Oceanography and Marine Biology: An Annual Review 41:161-236. [online\} URL: http://www.ecologia.it/ congressi/XIV/premi/airoldi.pdf

Agardy, T., G. Notarbartolo di Sciara and P. Christie. 2011. Mind the gap: addressing the shortcomings of marine protected areas through large scale marine spatial planning. Marine Policy 35 (2):226-232. http://dx.doi.org/10.1016/j.marpol.2010.10.006

Armsworth, P. R., K. Chan, M. A. Chan, G. C. Daily, C. Kremen, T. H. Ricketts, and M. A. Sanjayan. 2007. Ecosystem-service science and the way forward for conservation. Conservation Biology 21(6):1383-1384. http://dx.doi.org/10.1111/ j.1523-1739.2007.00821.X

Bielecki, J. 2002. Energy security: is the wolf at the door? The Quarterly Review of Economics and Finance 42:235-520.

Boyes, S. J., M. Elliott, S. M. Thomson, S. Atkins, and P. Gilliland. 2007. A proposed multiple-use zoning scheme for the Irish Sea: an interpretation of current legislation through the use of GISbased zoning approaches and effectiveness for the protection of nature conservation interests. Marine Policy 31(3):287-298. http://dx.doi.org/10.1016/j.marpol.2006.08.005

Brodin Y., and M. Andersson. 2009. The marine splash midge Telmatogon japonicus (Diptera; Chironomidae) - extreme and alien? Biological Invasions 11(6):1311-7. http://dx.doi.org/10.1007/ s10530-008-9338-7

Busch, M., A. Kannen, S. Garthe, and M. Jessopp. 2013. Consequences of a cumulative perspective on marine environmental impacts: offshore wind farming and seabirds at North Sea scale in context of the EU Marine Strategy Framework Directive. Ocean and Coastal Management 71:213-224. http://dx. doi.org/10.1016/j.ocecoaman.2012.10.016

Calado H., K. Ng, D. Johnson, L. Sousa, M. Phillips, and F. Alves. 2010. Marine spatial planning: lessons learned from the 
Portuguese debate. Marine Policy 34(6):1341-1349. http://dx.doi. org/10.1016/j.marpol.2010.06.007

Carstensen J., O. D. Henriksen, and J. Teilmann. 2006. Impacts of offshore wind farm construction on harbour porpoises: acoustic monitoring of echolocation activity using porpoise detectors (T-PODs). Marine Ecology Progress Series 321:295308. http://dx.doi.org/10.3354/meps321295

Cinnirella, S. R. Sardà, J. Suárez de Vivero, R. Brennan, A. Barausse, J. Icely, T. Luisette, D. March, C. Murciano, A. Newton, T. O’Higgins, L. Palmeri, M. Palmieri, P. Raux, S. REes, J. Albaigés, N. Pirrone, and K. Turner. Steps toward a shared governance response for achieving Good Environmental Status in the Mediterranean Sea. Ecology and Society 19(4): 47. http:// dx.doi.org/10.5751/ES-07065-190447/

Cochrane, S. K. J., D. W. Connor, P. Nilsson, I. Mitchell, J. Reker, J. Franco, V. Valavanis, S. Moncheva, J. Ekebom, K. Nygaard, R. Serrão Santos, I. Narberhaus, T. Packeiser, W. van de Bund, and A. C. Cardoso. 2010. Marine Strategy Framework DirectiveTask Group 1 report on biological diversity. EUR 24337 EN. Joint Research Centre, Office for Official Publications of the European Communities, Luxembourg City, Luxembourg.

Curtin, R., and R. Prellezo. 2010. Understanding marine ecosystem based management: a literature review. Marine Policy 34(5):821-830. http://dx.doi.org/10.1016/j.marpol.2010.01.003

Cooper, P. 2013. Socio-ecological accounting: DPSWR, a modified DPSIR framework, and its application to marine ecosystems. Ecological Economics 94:106-115. http://dx.doi. org/10.1016/j.ecolecon.2013.07.010

Davies A., J. M. Roberts, and J. M. Hall-Spencer. 2007. Preserving deep-sea natural heritage: emerging issues in offshore conservation and management. Biological Conservation 138(34):299-312. http://dx.doi.org/10.1016/j.biocon.2007.05.011

Dayton, P., S. Curran, A. Kitchingman, M. Wilson, A. Catenazzi, J. Restrepo, C. Birkeland, S. Blaber, S. Saifullah, G. Branch, D. Boersma, S. Nixon, P. Dugan, N. Davidson, and C. Vorosmarty. 2005. Coastal systems. Pages 513-550 in T. Agardy and J. Alder, editors. Ecosystems and human well-being: current status and trends. Millennium Ecosystem Assessment, Island Press, Washington, D.C., USA.

Department for Environment, Food \& Rural Affairs (DEFRA). 2012. Government response to the informal consultation on the European Maritime and Fisheries Fund. DEFRA, London, UK. [online] URL: http://www.defra.gov.uk/consult/files/emff-consultresponse-20120921.pdf

Douvere, F. 2008. The role of marine spatial planning in advancing ecosystem-based sea use management. Marine Policy 32:762-771. http://www.unesco-ioc-marinesp.be/uploads/ documentenbank/814d218d791bf6f33fd9b0d78139acf6.pdf

Douvere, F., and C. Ehler. 2009. New perspectives on sea use management: initial findings from European experience with marine spatial planning. Journal for Environmental Management 90(1):77-88. http://dx.doi.org/10.1016/j.jenvman.2008.07.004

Ehler, C. and F. Douvere. 2009. Marine spatial planning: a stepby-step approach toward ecosystem-based management. Intergovernmental Oceanographic Commission (IOC) Manual and Guides No. 53.
Integrated Coastal Area Management (ICAM) Dossier No. 6. Intergovernmental Oceanographic Commission and Man and the Biosphere Programme, UNESCO, Paris, France. [online] URL: http://unesdoc.unesco.org/images/0018/001865/186559e.pdf

European Commission (EC). 2008. Roadmap for maritime spatial planning: achieving common principles in the EU. Communication 791 from the Commission. EC, Brussels, Belgium. [online] URL: http://eur-lex.europa.eu/legal-content/EN/TXT/? qid=1396432777228\&uri=CELEX:52008DC0791

European Commission. 2010. Maritime spatial planning in the EU - achievements and future development. Communication 771 from the Commission to the European Parliament, the Council, the European Economic and Social Committee and the Committee of the Regions. EC, Brussels, Belgium. [online] URL: http://ec. europa.eu/maritimeaffairs/documentation/publications/documents/ com 2010771 brochure en.pdf

European Commission. 2013. Proposal for a Directive of the European Parliament and of the Council establishing a framework for maritime spatial planning and integrated coastal management. COM(2013) 133 final. EC, Brussels, Belgium. [online] URL: http://ec.europa.eu/environment/iczm/pdf/Proposal en.pdf

European Commission. 2014. Directive 2014/89/EU of the European Parliament and of the Council of 23 July 2014 establishing a framework for maritime spatial planning. Official Journal of the European Union L 257/135. [online] URL: http:// eur-lex.europa.eu/legal-content/EN/TXT/?uri=uriserv:OJ.

$\underline{\mathrm{L}}$.2014.257.01.0135.01.ENG

European Council. 2003. Commission Regulation (EC) No $1475 / 2003$ of 20 August 2003 on the protection of deep-water coral reefs from the effects of trawling in an area north west of Scotland. Official Journal of the European Union L 211:14-15. [online] URL: http://eur-lex.europa.eu/legal-content/EN/TXT/? uri=uriserv:OJ.L .2003.211.01.0014.01.ENG

European Union. 2001. Directive 2001/42/EC of the European Parliament and of the Council of 27 June 2001 on the assessment of the effects of certain plans and programmes on the environment (Directive on Strategic Environmental Assessment). EU, Brussels, Belgium. [online] URL: http://eur-lex.europa.eu/ legal-content/EN/TXT/?uri=CELEX:32001L0042

European Union. 2007. Communication from the Commission to the European Parliament, the Council, the European Economic and Social Committee and the Committee of the Regions - an Integrated Maritime Policy for the European Union $\{\mathrm{COM}(2007) 574$ final) $\}$. EC, Brussels, Belgium. [online] URL: http://eur-lex.europa.eu/legal-content/EN/TXT/?uri= CELEX:52007DC0575

European Union. 2008. Directive 2008/56/EC of the European Parliament and of the Council of 17 June 2008 establishing a framework for community action in the field of marine environmental policy (Marine Strategy Framework Directive). Official Journal of the European Union L 164/19. [online] URL: http://eur-lex.europa.eu/LexUriServ/LexUriServ.do?uri=OJ: L:2008:164:0019:0040:EN:PDF

Falcão, M., M. N. Santos, T. Drago, D. Serpa, and C. Monteiro. 2009. Effect of artificial reefs (southern Portugal) on sedimentwater transport of nutrients: importance of the hydrodynamic 
regime. Estuarine, Coastal and Shelf Science 83(4):451-459. http://dx.doi.org/10.1016/j.ecss.2009.04.028

Farmer, A., L. Mee, O. Langmead, P. Cooper, A. Kannen, P. Kershaw, and V. Cherrier. 2012. The ecosystem approach in marine management. EU FP7 KNOWSEAS Project. European Commission, Brussels, Belgium. [online] URL: http://www. knowseas.com/links-and-data/policy-briefs/D2_4 final.pdf/view

Fayram, A. H., and A. de Risi. 2007. The potential compatibility of offshore wind power and fisheries: an example using bluefin tuna in the Adriatic Sea. Ocean and Coastal Management 50 (8):597-605. http://dx.doi.org/10.1016/j.ocecoaman.2007.05.004

Frazão Santos, C., Z.G. Teixeira, J. Janeiro, R. S. Gonçalves, R. Bjorkland, and M. Orbach. 2012. The European marine strategy: contribution and challenges from a Portuguese perspective. Marine Policy 36(5):963-968. http://dx.doi.org/10.1016/j. marpol.2012.02.011

Gee, K., A. Kannen, and B. Heinrichs. 2011. BaltSeaPlan vision 2030 - towards the sustainable planning of Baltic Sea space. [online] URL: http://www.baltseaplan.eu/index.php/BaltSeaPlanVision-2030;859/1

Gilliland, P. M., and D. Laffoley. 2008. Key elements and steps in the process of developing ecosystem-based marine spatial planning. Marine Policy 32(5):787-796. http://dx.doi.org/10.1016/ j.marpol.2008.03.022

Haggett, C. 2008. Over the sea and far away? A consideration of the planning, politics and public perception of offshore wind farms. Journal of Environmental Policy and Planning 10(3):289306. http://dx.doi.org/10.1080/15239080802242787

Halpern, B., J. Diamond, S. Gaines, S. Gelcich, M. Gleason, S. Jennings, S. Lester, A. Macei, L. McCook, K. McLeod, N. Napoli, K. Rawson, J. Rice, A. Rosenberg, M. Ruckelshaus, B. Saier, P. Sandifer, A. Scholz, and A. Ziviant. 2012. Near-term priorities for the science, policy and practice of Coastal and Marine Spatial Planning (CMSP). Marine Policy 36(1):198-205. http://dx.doi. org/10.1016/j.marpol.2011.05.004

Hall-Spencer J. M., V. Allain, and J. H. Fossa. 2002. Trawling damage to northeast Atlantic ancient coral reefs. Proceedings of the Royal Society London B 269(1490):507-511. http://dx.doi. org/10.1098/rspb.2001.1910

Hall-Spencer J., M. Tasker, M. Soffker, S. Christiansen, S. Rogers, M. Campbell, and K. Hoydal. 2009. Design of marine protected areas on high seas and territorial waters of Rockall Bank. Marine Ecology-Progress Series 397:305-308. http://dx.doi.org/10.3354/ $\underline{\text { meps08235 }}$

Hiddink, J. G., S. Jennings, and M. J. Kaiser. 2006. Indicators of the ecological impact of bottom-trawl disturbance on seabed communities. Ecosystems 9(7):1190-1199. http://dx.doi.org/10.1007/ $\underline{\text { s10021-005-0164-9 }}$

Hoffert, M. I., K. Caldeira, G. Benford, D. R. Criswell, C. Green, H. Herzog, A. K. Jain, H. S. Kheshgi, K. S. Lackner, J. S. Lewis, H. D. Lightfoot, W. Manheimer, J. C. Mankins, M. E. Mauel, L. J. Perkins, M. E. Schlesinger, T. Volk, and T. M. L. Wigley. 2002. Advanced technology paths to global climate stability: energy for a greenhouse planet. Science 298:981-987. http://dx.doi. org/10.1126/science. 1072357
Holling, C. S., editor. 1978. Adaptive environmental assessment and management. Wiley, Chichester, UK.

International Council for the Exploration of the Sea (ICES). 2012. Advice May 2012. Ecoregion: North Sea. Stock: herring in subarea IV and divisions IIIa and VIId (North Sea autumn spawners). ICES, Copenhagen, Denmark.

Jay, J., G. Ellis, and S. Kidd. 2012. Marine spatial planning: a new frontier? Journal of Environmental Policy and Planning 14:1-5.

Jentoft, S., and M. Knol. 2014. Marine spatial planning: risk or opportunity for fisheries in the North Sea? Maritime Studies 12:13. [online\} URL: http://www.maritimestudiesjournal.com/ content/pdf/2212-9790-13-1.pdf

Kannen, A. 2012. Challenges for marine spatial planning in the context of multiple sea uses, policy arenas and actors based on experiences from the German North Sea. Regional Environmental Change 14(6)2139-2150 http://dx.doi.org/10.1007/s10113-012-0349-7

Kappeler, B., S. Toben, G. Chmura, S. Walkowicz, N. Nolte, P. Schmidt, J. Lamp, C. Goke, and C. Mohn. 2012. Gee, K., editor. Developing a pilot maritime spatial plan for the Pomeranian Bight and Arkona Basin. BaltSeaPlan report 9. BaltSeaPlan, Hamburg, Germany. [online] URL: http://www.baltseaplan.eu/index.php/ Pomeranian-Bight;832/1

Kelly, C. L. Gray, R. Shucksmith, and J. F. Tweddle. 2014. Review and evaluation of marine spatial planning in the Shetland Islands. Marine Policy 46:152-160. http://dx.doi.org/10.1016/j.marpol.2014.01.017

Ladenburg, J. 2008. Attitudes towards on-land and offshore wind power development in Denmark: choice of development strategy. Renewable Energy 33(1):111-118. http://dx.doi.org/10.1016/j. renene.2007.01.011

Maritime Spatial Planning in the North Sea (Maspnose). 2012. Final report of the project: preparatory action on maritime spatial planning in the North Sea. Directorate-General for Maritime Affairs and Fisheries, European Commission, Brussels, Belgium.

Mee, L., P. Cooper, A. Kannen, A. J. Gilbert, and T. O’Higgins. 2015. Sustaining Europe's seas as coupled social-ecological systems. Ecology and Society 20(1): 1. http://dx.doi.org/10.5751/ ES-07143-200101

Millennium Ecosystem Assessment. 2005. Ecosystems and human well-being: synthesis. Island, Washington, D.C., USA.

O’Higgins, T., A. Farmer, G. Daskalov, S. Knudsen, and L. Mee. 2014. Achieving good environmental status in the Black Sea: scale mismatches in environmental management. Ecology and Society 19(3): 54. http://dx.doi.org/10.5751/ES-06707-190354

Petersen, J. K., and T. Malm. 2006. Offshore windmill farms: threats to or possibilities for the marine environment. $A M B I O$ : A Journal for the Human Environment 35(2):75-80. http://dx.doi. org/10.1579/0044-7447(2006)35[75:OWFTTO]2.0.CO;2

Pollnac, R., P. Christie, J. E. Cinner, T. Dalton, T. M. Daw, G. E. Forrester, N. A. J. Graham, and T. R. McClanahan. 2010. Marine reserves as linked social-ecological systems. Proceedings of the National Academy of Sciences of the United States of America 107(43):18262-18265. http://dx.doi.org/10.1073/pnas.0908266107 
Punt, M. J., R. A. Groeneveld and E. C. van Ierland. 2009. Spatial planning of offshore wind farms: a windfall to marine environmental protection? Ecological Economics 69:93-103.

Roberts, C. M., and N. V. C. Polunin. 1993. Marine reserves: simple solutions to managing complex fisheries? AMBIO: $A$ Journal for the Human Environment 22:363-8.

Sale, P. F., R. K. Cowen, B. S. Danilowicz, G. P. Jones, J. P. Kritzer, K. C. Lindeman, S. Planes, N. V. C. Polunin, G. R. Russ, Y. J. Sadovy, and R. S. Steneck. 2005. Critical science gaps impede use of no-take fishery reserves. Trends in Ecology and Evolution 20 (2):74-80. http://dx.doi.org/10.1016/j.tree.2004.11.007

Southall, B., A. Bowles, W. Ellison, J. Finneran, R. Gentry, C. R. Greene, Jr., D. Kastka, D. R. Ketten, J. H. Miller, P. E. Nachtigall, W. J. Richardson, J. A. Thomas, and P. L. Tyak. 2007. Marine mammal noise exposure criteria: initial scientific recommendations. Aquatic Mammals 33(4):411-521. http://dx.doi.org/10.1578/ $\underline{\text { AM.33.4.2007.411 }}$

Suárez de Vivero, J. L., and J. C. Rodríguez Mateos. 2012. The Spanish approach to marine spatial planning. Marine Strategy Framework Directive vs. EU integrated maritime policy. Marine Policy 36(1):18-27. http://dx.doi.org/10.1016/j.marpol.2011.03.002

Tougaard J., J. Carstensen, M. S. Wisch, J. Teilmann, N. Bech, H. Shokv, and O. D. Hendriksen. 2005. Harbour porpoises on Horns reef-effects of the Horns reef wind farm. Annual status report 2004 to Elsam. National Environmental Research Institute (NERI), Roskilde, Denmark.

United Nations Environment Programme(UNEP). 2006. Marine and coastal ecosystems and human well-being: a synthesis report based on the findings of the Millennium Ecosystem Assessment. UNEP, Nairobi, Kenya. [online] URL: http://www.unep.org/pdf/ Completev6_LR.pdf

UNESCO. 2013. Marine spatial planning initiative. UNESCO, Paris, France. [online] URL: http://www.unesco-ioc-marinesp.be/ msp around the world

Vision and Strategies Around the Baltic Sea (VASAB) Committee on Spatial Development. 2010. VASAB long-term perspective for the territorial development of the Baltic Sea region. VASAB Secretariat, Riga, Latvia. [online] URL: http://www.vasab.org/ index.php/long-term-perspective

Walhberg, M., and H. Westerberg. 2005. Hearing in fish and their reactions to sounds from offshore wind farms. Marine Ecology Progress Series 288:295-309. http://dx.doi.org/10.3354/meps288295

Wilhelmsson, D., T. Malm, and M. C. Öhman. 2006. The influence of offshore windpower on demersal fish. ICES Journal of Marine Science 63:775-784. http://dx.doi.org/10.1016/j. icesjms.2006.02.001

Worm B. 2006. Impacts of biodiversity loss on ocean ecosystem services. Science 314:787-790. http://dx.doi.org/10.1126/science.1132294

Worm B., E. B. Barbier, N. Beaumont, J. E. Duffy, C. Folke, B. S. Halpern, J. B. Jackson, H. K. Lotze, F. Micheli, S. R. Palumbi, E. Sala, K.A. Selkoe, J. J. Stachowicz, and R. Watson. 2006. Impacts of biodiversity loss on ocean ecosystem services. Science 314:787-790.
Zaucha, J., and M. Matczak. 2012. Identification of maritime spatial planning best practices in the Baltic Sea Region and other European Union maritime regions. Instytut Morski w Gdańsku, Gdańsk, Poland. 